\title{
The Political Communication in General Election Designed by DPW PBB (Partai Bulan Bintang), North Sumatra, Indonesia
}

\author{
Hasrat Efendi Samosir \\ Ph.D Student of State Islamic University of North Sumatra (UINSU), Medan, Indonesia \\ Lecturer at Da'wah Faculty, State Islamic University of North Sumatra, Medan, Indonesia
}

\begin{abstract}
Religion can be seen as an instrument of ilahiah to understand Islam, compared by other religions. It is actually the easiest religion to accept the premise like this. The main reason lies in the most prominent characteristic of Islam that is its omnipresence; the presence of Islam always gives the true moral guide for human beings. Political communication consists of two syllables; communication and politics, which is a series of words that if they are separated, each has a meaning. Communication is everywhere: at home, when family members discuss at the dinner table; on campus, when students discuss the results of testaments'; in the office, etc. Based on the research that has been done, it can be concluded that there are three forms of political communication conducted by Partai Bulan Bintang (PBB), they are: communications in the form of mass communication, group communication and interpersonal communication. So that there are three forms of communication described in this study, namely mass communication, group communication and interpersonal communication.
\end{abstract}

Keywords: Al Qur'an; Partai Bulan Bintang (PBB); political communication; political message

\section{INTRODUCTION}

Religion, as stated many people, can be seen as an instrument of ilahiah to understand Islam, compared to other religions, it is actually the easiest religion to accept the premise like this. The main reason lies in the most prominent characteristic of Islam that is its omnipresence; the presence of Islam always gives the true moral guide for human beings. This view has forced several of its adherents to believe that Islam covers a total way of life. The Inception expressed in the form of Sharia (Islamic law). Even some Muslims go further than that: they stress that "Islam is a coherent totality which offers solutions to all the problems of life." Undoubtedly, they believe the perfect and complete nature of Islam so that in their opinion, Islam covers the famous three "Ds" (din; religion, dunya; world and dawlah; state). Therefore, Islam becomes a totality guide and must be applied in family, economics and politics life. For Muslims it is imagined in the creation of an Islamic state, namely an ideological state which is based on the complete teachings of Islam.

In the context of today, it is not too surprising, although sometimes it is worrying that the contemporary Islamic world witnesses some Muslims who want to base the entire framework of social, economy and politics life in the teachings of Islam exclusively, without recognizing the limitations and constraints that will arise in the practice. The expressions can be found some symbolist terms which are popular today such as Islamic revivalism, the revival of Islam, the revolution of Islam or fundamentalism of Islam. Meanwhile such expressions are driven by a sincere intention, it cannot be denied that all of them are less thought out carefully and in in fact they are more are apologetic. The holistic view of Islam as mentioned above has some implications. One of them is that this view has led to the birth of a tendency to understand Islam in "literal" by only emphasizing the "outside" dimension of "its exterior". And this tendency has been developed so far that causes the negligence of "contextual" dimension and "interior" of the principles of Islam. The emergence of various mazhab fiqh, theology, and philosophy of Islam, for example, shows that the teachings of Islam are multi-interpretative, this multi-interpretative has served as the basis of elasticity of Islam in history; the rest also hints the requirement of pluralism in Islamic tradition. Therefore as has been said by many Muslims, it cannot and should be viewed mono-litical. The above view gives that in the implications of political life of Islam it cannot be separated from the multi-interpretative history of Islam like this. On the other hand, almost every Muslim believes the importance of the principles of Islam in political life. At the same time, because of the multi-interpretative nature of Islam, there is no single view on how Islam and politics should associated correctly. In fact, as far as that can be captured from the travel of intellectual discourse and historical thinking as well as Islamic political practice, there are many different opinions, even some are conflicting about the appropriate relationship between Islam and politics. 
II. METHODOLOGY

Political communication consists of two syllables; communication and politics, which is a series of words that if they are separated, each has a meaning. Communication is everywhere: at home, when family members discuss at the dinner table; on campus, when students discuss the results of testaments'; in the office, when the division head divides the tasks; in the mosque, when preachers preach; in the People's Representative Assembly, when the people's representatives decide the fate of the nation; as well as in a park-garden when a lover expresses his longing to his vengeance. Communication touches all aspects of our lives. A study revealed that $70 \%$ of our waking hours are used to communicate. Communication determines the quality of our lives. With communication we establish a mutual understanding, foster a friendship, keep the affection, disseminate knowledge, and preserve a friendship. But with communication we also nourish discord, enmity turn, instill hatred, impede the progress and hinder the thinking. The communication is so important, so widespread and so familiar with us so that we all feel there is no need to learn communication.

According to the language "communication" comes from the Latin word, "communicatio", and from the word "communis" which means "equal". The meaning of 'equal' here is 'equal in meaning'. Meanwhile the experts of communication state the different opinions in accordance with their own views respectively. The meaning of communications in terminology is first, according to Carl I. Houland "Communication is the process by which an individual (the communicator) transmit stimuli (usually verbal symbols) to modify the behavior of the individuals (communicates). Second, William Ablig in his book "Public Opinion" states "Communication is the process of transmitting meaningful symbols between individuals". Warren Weaver in his book "The Mathematics of Communication" states: "Communication includes all the procedures by which one mind can affect another."

The political communication study at the beginning is rooted in political science, although the naming is more known as propaganda. It started in 1922 with the research of Ferdinand Tonnies and Walter Lippmann who studied the public opinion on society, then it followed by Bagehot, Maine, Byrce, and Graha Wallas in the UK who examine the role of press and the public opinions. Even when Harold D Lasswell wrote a doctoral dissertation on Propaganda Technique In the War (1927). The practice of propaganda developed especially before the World War II when Nazi Germany managed to expand brilliantly under the propaganda of Dr. Joseph Gobbel. Learning from that experience, the United States who first saw propaganda had a negative connotation and amoral, began to realize its usefulness and developed this field so that before the World War II, a number of experts were employed in the office of war information of US, among them were Carl L Hovland (social psychology), Kurt Lewin (social group), Lucian Pye (politics), Gordon Allport (gossip and rumors), and Schramm (content analysis). Thanks to the pioneering of Lasswell's dissertation, then Wilbur Schramm put Laswell as a main figure in the study of political communication, followed by other works, among them Propaganda and Promotional activities; An Annotated Bibliography by Lasswell with Ralph D. Casey and Bruce L Smith (1935), which was later developed into propaganda, Communication, and Public Opinion (1956). Other political scientists who have important roles in communication and political discipline are Ithiel de Sola Pool, V.O. Key, and Gabriel Almond.

In Indonesia, at the beginning of attention to discuss political communications grew among the scientists or scholars in political science rather than the scientists and scholars of communication science itself. However, it is not too outdated since the mid-1980s, the majors of communication science began to teach political communication studies, though they did not focus yet and still widely supported by the material of public opinions and the effects of mass media on political behavior. Even up to 1991, Prisma magazine which published a special edition about communication and power (political) could not touch the substance of this science yet for what is meant by political communication. Therefore, the definitions of political communication made at that time relied more heavily on political behavior, and did not touch substantially on the role of the mass media toward the rule of democracy, campaign and election.

The study of political communication is a little bit slow to develop in Indonesia; this is mainly due to the new order regime that disliked with the things related to politics, disliked with the press freedom and the true democracy climate. In this regime the election only a routine as a stamp to be called democracy, political parties were forced into only three parties, for People's Representative Assembly and People's Consultative Assembly besides the three parties there were still the Military (ABRI), groups and region delegations who were appointed by the president and not through the people's election process. Since the fall of new order regime, then it came to reform era and so the life of democracy was opened widely and brought the freedom of expression that was rolled out since 1998, then the study of political communications experienced rapid development, so that this study becomes an interesting study of science not only for students of communication but also for the political science, law and constitution instigators. Just like other communications disciplines, political communication as 
a body of knowledge also consists of various elements; they are: the source (communicator), messages, media or channel, receiver and feedback. ${ }^{1}$

\section{a. Political Communicator}

Political communication is not just about political parties, but also the legislative and executive government agencies. Thus, the sources or political communicator are those who can give information on matters which contain the meaning or political things, such as the President, Ministers, Governors, Regents, Mayor, People's Consultative Assembly (MPR), People's Representative Assembly (DPR), Regional Representative Assembly (DPD), General Election Committee (KPU), Regional People's Representative Assembly (DPRD), politicians, functionaries of political party, functionaries of Non-Governmental Organizations (NGOs) and the pressure groups in the community who can influence the process of the government.

\section{b. Political message}

Political message is statement delivered in written or unwritten, verbal and non-verbal, covert and overt, either consciously or unconsciously that the contents is about political things. For examples political speech, the rules of the party, the general election regulations, political statements, articles or books/brochures and newspapers, radio, television and the Internet that contain reviews of politics, propaganda, psywar, the meaning of logo, the shirt or flag colors, body language, and things like them.

\section{c. Channel or Political Media}

Channel or political media is the means used by the communicator in conveying the political messages. For examples, the print media such as newspapers, tabloids, magazines and books. Electronic media, like films, radios, televisions, videos, computers, and internet. Small format media, such as leaflets, brochures, flyers, stickers, bulletin. Outdoor media such as billboards, banners, billboards, electronic boards, flags, tassels, pin, logo, hats, vests, T-shirts, advertising cars, railway carriages, calendars, book covers, block notes, pens, key chains, umbrellas, handbags, the covers of prayer book, the covers of mineral drinks and everything that is used to build an image, communication channel groups, such as political party (DPP, DPW, DPD, DPC, DPAC / DPRT, RAYON), professional organizations, alumni associations, religions social organizations, cadets, prayer groups, majlis taklim, groups of farmers and fishermen, cooperatives, sports unity, groups of neighborhood, talent and interest associations and things like them. Public communication channels, for example, halls, meeting halls, village halls, exhibition, square, stage arts, markets, supermarkets (supermarkets, malls, plazas), schools, colleges. Social communication channels, such as weddings, circumcision ceremony, gathering, cultural performances such as puppet, tor-tor, and others, party of the people, home security, public wells, the party of farmers, and the like.

\section{d. Political Target}

The target is the community members who are expected to provide supports in the form of vote to the party or candidate in a general election or a political election. They are constituents or the people who already have the rights to vote to use their political rights of either they are employers, civil servants (PNS), labor, youth, farmers, women, private sector employees, housewives, retirees, veterans, street vendors, artisans (wood, stone, shaving, tricycles) disabled, college students, blind peoples, transport drivers, professors, teachers, fishermen, students or young people who already have the right to select at the age of 17 years. All of them have become the political targets, as communicants who should be grabbed their sympathy and vote.

\section{e. The Feedback or the Effect of Political Communication}

The expected effect of political communication is the understanding of the government and political parties systems in which it will lead to the provision of vote in the general elections. The voting is crucial to elect whether or not a candidate for the position starting from the President and Vice President, Governor and Vice Governor, Regent and Vice Regent, Mayor and Deputy Mayor, members of Parliament, Assembly, Council, Parliament, including being chosen a certain political party. Because of the importance of the political effect, the political education performed by political parties is a must give to the public.

\section{DISCUSSION}

The forms of communication examined here include mass communication, group communication and interpersonal communication. So that there are three forms of communication that the researcher will describe in this study, namely mass communication, group communication and interpersonal communication. Besides, the findings and the analysis of the study are also focused on political communication elements include: political communicators, political messages, channels or political media, the targets or political communicants, and the

\footnotetext{
${ }^{1}$ Hafied Cangara, Komunikasi Politik; Konsep, Teori dan Strategi, (Jakarta: Rajawali Pers, 2009), p. 37 
feedback or the effect of political communication. Some political communication done by Partai Bulan Bintang (PBB), North Sumatra in general election:

\section{A. Interpersonal Communication}

Interpersonal communication (IC) is a communication which takes place in face to face situations between two or more persons, either organized or on a group of people, two directions, verbal and non-verbal, the attitude of mutual sharing in information, and the feelings between individuals in a small group. Miller says that understanding the interpersonal communication process requires an understanding of symbiotic relationship between communications with the relations development. Therefore this interpersonal communication greatly influences the development of relations simultaneously and involves various parties in the relationship. Through interpersonal communication, one can change his attitudes and behavior and others, change the opinions of others, and help others. Also, by interpersonal communication one can have a relationship with someone else, and make himself as an agent that can transform himself and make himself and the environment as he desires. This shows that interpersonal communication is considered as a learning process towards a better change.

The above opinions are in accordance with the Muhammad's opinion who says that interpersonal communication is a process of information exchange between someone with others, or more immediately known as feedback. Or in other words, interpersonal communication gives direct effect to the communicators. ${ }^{2}$

The characteristics of interpersonal communication we can see as follows:

a. Being in a close distance,

b. Sending and receiving messages simultaneously and spontaneously, either verbally or non-verbally

c. Informal

d. Unplanned

e. The caused effects (cognition enhancing the views, knowledge, attitudes affective, psychomotor behavior change) because they are in the forms of face to face or direct.

Meanwhile, according to Hardjana interpersonal communication principles are:

a. Involving in the verbal and non-verbal behavior.

b. Involving the spontaneous, precise, and rational behaviors.

c. Interpersonal communication is not static, but dynamic.

d. Involving personal feedback, interaction and coherence (a statement that should be related to the others previously)

e. Interpersonal communication is guided by intrinsic and extrinsic rules and regulations.

f. Interpersonal communication is an activity and action.

g. Involving in it the field of persuasive.

Then, according to Evert M. Rogers in Depari (1988) the interpersonal communication principles are:

a. the messages flow that tend to be two-way

b. the context of its communication is face to face

c. The level of feedback is high

d. Ability to cope with the level of selectivity, especially selective the high exposure.

e. the speed range to a large audience is relatively slow.

f. the possible effect that may happen is an attitude change.

Furthermore, according to Judy C. Pearson, the interpersonal communication principles are:

a. Interpersonal communication is started with self. Various perception of communications that concerning our self-centered meanings

b. Interpersonal communication is transactional. This assumption refers to the parties who communicate simultaneously and are parallel, conveying and receiving the messages.

c. Interpersonal communication includes aspects of the message contents and personal relationships.

d. Interpersonal communication requires physical proximity between communicating parties

e. Interpersonal communication involves parties who depend on each other in the communication process

f. Interpersonal communication cannot be modified or repeated.

To help the purposes of interpersonal communication are: first, to convey information, second, to share the experiences, third, to develop the sympathy, fourth to cooperate and fifth, to develop motivation. ${ }^{3}$ While the

\footnotetext{
${ }^{2}$ HerriZan Pieter, Pengantar Komunikas idan Konseling ,( Jakarta : KencanaPrenada Media Group, 2012) p 9293

${ }^{3}$ Julia T Wood. Komunikasi Teori dan Praktik ( Jakarta : SalembaHumanika, 2013) p 96

DOI: 10.9790/0837-2204066875 www.iosrjournals.org $71 \mid$ Page
}


advantages and disadvantages of interpersonal communication, namely: first, the advantages. This face to face interpersonal communication has many advantages, they are:

a. The feedback between the communicator and the communicant will be received quickly and also can see the reaction that becomes the non-verbal communication from the communicant itself.

b. There is an emotional closeness because of the intensity of communication.

c. Able to reduce the noise in communication because it occurs immediately and if there is a direct interference, it can be confirmed.

d. Able to convey a message with only a non-verbal communication without verbal communication.

e. No need payment in doing so because it is done immediately and continuously. So chatting in a long period of time does not need any cost.

f. The emotions or feelings between the communicator and the communicant are more involved and reduce lies because of their faces will be seen directly by the interlocutor.

Besides having the advantages, face to face interpersonal communication also has some disadvantages, as for its shortcomings, namely:

1. Regarding the efficiency of time, which meant here is the efficient time to meet. Everyone has his own busy activities so as to perform face to face communication it needs the right time so that both can meet and complement the face to face interpersonal communication

2. Unable to communicate with people in different places because of the face to face range is very limited so that it requires media to connect each other in order to communicate. So in this face to face the obstacles are a limited time and scope. ${ }^{4}$

This kind of interpersonal communication is also implemented in DPW of PBB of North Sumatra. The communication between the personnel committee intensely is done by emphasizing the importance of establishing Ukhwah Islamiyah and relationship. Likewise in approaching the sympathizers and the public or constituents, PBB officials always put Ukhwah or bond in every meeting. Each officials of DPW PBB of North Sumatra both personals or leaders are required to have mission as dua'at or dai, as Allah says in Surah Ali Imran 104:

Meaning: "And let none of you are calling a class of people to virtue, sent to ma'ruf and prevent it from munkar; they are the lucky ones".

As well as the words of Allah Surah an-Nahl: 125

Meaning: "Invite (all) to the way of your Lord with wisdom and goodly exhortation, and argue with them in a good way. Surely your Lord knows best who has strayed from His path, and He knows best those who receive guidance."

As the bearers of the dakwah mission, of course every staff and leader of PBB of North Sumatra are required to carry out syariat Islam in kaffah way, including in the interaction each other. Silaturahim or friendship in Islam covers five dimensions, namely Taaruf (mutual acquantance), Tafahum (mutual understanding), Tahabbun (mutual love), Taawun (mutual help) and Takaful (mutual protection). Brotherhood among the believers has been explained by Allah in Surah Ali Imran: 103 and Surah Al-Hujurat: 10:

Meaning: "And hold you all to the straps (religion) of Allah, and be not disunited, and remember the favor of Allah unto you when you first (period of Ignorance) hostile hostility, then He united your hearts, and then becomes for you for the favor of God, who are brothers; and ye were on the brink of a pit of fire, then He saved you from it. Thus Allah makes His revelations unto you, that ye may be guided."

Next Surah Al Hujurat: 10

Meaning: "People believe it truly brothers. Therefore make peace (improve relations) between the two brothers and fear Allah, that you may receive mercy".

\section{B. Group Communication}

Humans basically want to live in groups; sometimes they have different perceptions and goals from one group with another. This is tied by time and space, also differentiated by culture or cultural background of the group itself. Regarding to these differences, there usually happens in ethnic associations, let alone if we talk about the minority and the majority ethnics. The excessive superior in group feeling of inferiority by regarding to out group. ${ }^{5}$

Kartini Kartono says that group is composed of two or more individuals, and their presence has meaning and value to others, and exist in each other influence situations. Andrik Purwasito gives the meaning of

\footnotetext{
${ }^{4}$ Fatmig2.blogspot.co.id/2012/09/komunikasi-interpersonal.html

5 Andrik Purwasito, Komunikasi Multikultural (Surabaya: UMS Press, 2003), p 165

DOI: $10.9790 / 0837-2204066875 \quad$ www.iosrjournals.org $\quad 72 \mid$ Page
}


group as some people who are based on same similarities such as perception, motivation, and their goals in the group. 6

Miftah Thohah provides a definition of the group, is not independent of the forming group itself. It also cannot let go of the prominent characteristics of the group, namely:

1.1. The presence of two or more people

1.2. Interacting each other

1.3. Sharing some of the same goals

1.4. Seeing himself as a group.

\section{Mass Communication}

Mass communication is a process in which media organizations create and spread the messages to the audience (public). The media organizations will disseminate the messages that will affect and reflect the culture of a society, and then they will present this information simultaneously at widely diverse audiences. This makes the media become part of a powerful institution in the society. In mass communication, mass media becomes the sole authority to select, to produce the message and to deliver it to the audiences.

Mass communication can be defined as a process of communication which is done through the mass media, either in printed or electronic media. The printed media such as newspapers, newsletters, magazines, periodicals etc. While the electronic media such as radio, television, film, advertising on television, including the electronic media which is very influential at this time that is the internet (on the internet there also has social media such as BBM, Line, WA, Facebook and Twitter).

All the media mentioned are including the mass media. So that mass communication is a communication that uses a variety of media. There is also a mass media that is public open space, which can take tens or even hundreds of thousands people. For example, a grand campaign in public open spaces such as courts, football stadiums, arenas etc. All of which use the media portion of the instrument of mass communication. Mass communication is important and must be committed by political parties, including the Partai Bulan Bintang Sumatera Utara (Star and Crescent Party of North Sumatra) because this type of communication has many advantages that are not owned in interpersonal and group communication. The advantages include:

a. The cost is cheap, because it does not need much equipment

b. With little cost then the spreading is fast.

c. Illiteracy is not a constraint. Because of listening to through a listening device

d. Can be enjoyed while doing other activities.

e. Can overcome the limitations of space and time.

f. Whenever and wherever the images can be viewed and used.

g. The cost is cheap and easy to obtain and use.

$\mathrm{h}$. The nature is concrete, straightforward and direct to the matter point.

i. Many contents. It can be pages.

j. Can be read many times.

k. Sharp analysis, so that the readers can understand the content of the news.

However, mass communication still has disadvantages, they are:

a. It depends on the weather conditions. If the condition is not good then the sound generated is also not maximal.

b. Some mass media present very few contents. They cannot present as many as other media.

c. TV Media and the Internet only show the eye perception. The blind people cannot use this media.

d. people's perceptions are different so that they create many meanings and interpretations.

e. Some image media are only presented in small sizes that make them less effective in understanding the contents.

f. Media such as TV takes expensive cost. Because it must use much equipment and requires many crews,

g. For printed media, they are less quick in reporting the news because of having to wait for the printing.

h. No audio-visual equipment. Printed media can only be enjoyed by the senses of vision, and those who are able to read

i. It's too complicated in producing, because it must go through many processes.

j. Some media in reporting the news are less accurate, unlike other media

$\mathrm{k}$. Limited to those who can run the internet.

1. Limited to the network. If there is no network then it will not be able to access the internet.

\footnotetext{
${ }^{6}$ Ibid, h. 165

${ }^{7}$ Miftah Thoha, Prilaku Organisasi; Konsep Dasar dan Aplikasinya (Jakarta: RajaGrafindo Persada, 2004), p. 84 
Factually, based on the information and search committed by the researcher found that the form of mass communication also happens in PBB of North Sumatra. The mass communication which is a kind of communication uses mass media, both printed and electronic. Then the form of mass communication done includes press releases or conveying news relate to the parties especially in addressing an issue through the media of newspapers. Likewise, a number of news through the newspapers that carried by the party leaders or candidates. However, the intensity the use of the news media is limited even very rare. But the researcher also found some writings of Dr. Masri Sitanggang in Waspada newspaper which got quite well response from the readers. His writings are mainly related to political Islam, Pancasila and the state. Dr. Masri sitanggang as the leader of PBB of North Sumatra before deciding to take part in the politics, is known as a academician or lecturer at his alma mater of University of North Sumatra. Besides that he also a dakwah activist who gave much training and cadetting. Although his education background is agriculture degree, but his understanding on the Islamic knowledge is also very qualified and he masters it. There are a number of books written by him about Tauhid.

The other mass media found in PBB of North Sumatra are biweekly official magazine, the name of the magazine Abadi taken from the name of the first magazine of Masyumi. The publication of this magazine is very useful to be a medium of information for leaders, cadres, members and the wide community. The magazine delivers news and the official state of PBB, as well as studies of Islam and community politics and nationality.

\section{CONCLUSION}

Based on the research that has been done, it can be concluded that there are three forms of political communication conducted by Partai Bulan Bintang (PBB), they are: communications in the form of mass communication, group communication and interpersonal communication. So that there are three forms of communication described in this study, namely mass communication, group communication and interpersonal communication. Besides, the findings and the analysis of the study are also focused on political communication elements include: political communicators, political messages, channels or political media, targets or political communicants, and the feedback or effect of political communication.

\section{REFERENCES}

[1] Ahmad, Zainal Abidin, Piagam Nabi Muhammad Saw. Konstitusi Negara yang pertama di dunia. Jakarta: Bulan Bintang, 1973.

[2] Amin, Ahmad, Fajr a-Islam, Kairo: Maktabat al-Nahdhat al Mishriyat, 1979.Banfield, Edward C, Political Infleunce. New York: The Free Pessof Glencoe, 1961.

[3] Bungin, Burhan, Analisis Data penelitian Kualitatif. Jakarta: Raja Grafindo Persada, 2005.

[4] Catlin, G.E.G, The Study of Principlesof Politics. New York: Macmillan, 1930.

[5] Cangara, Hafied, Pengantar Ilmu Komunikasi. Jakarta: PT Raja Grafindo Persada, 1998.

[6] Departemen Pendidikan dan Kebudayaan, Kamus Besar Bahasa Indonesia. Jakarta: Balai Pustaka, 1988.

[7] Direktur Jenderal Pembinaan Kelembagaan Islam, Depag RI, Sejarah dan Kebudayaan Islam. Ujungpandang: IAIN Alauddin Press, 1982.

[8] Dudung, Abdurrahman dkk, Sejarah Peradaban Islam dari Masa Klasik hingga Modern. Yogyakarta: Fakultas Adab IAIN Sunan Kali Jaga- Lesfi, 2002.

[9] Easton, David, The Political System. New York: Alfred A Knopf, 1953.

[10] Effendy, Bahtiar, Islam dan Negara ; Transpormasi Pemikiran dan Praktek Politik Islam di Indonesia. Jakarta: Paramadina, 1998.

[11] Eriyanto, Kekuasaan Otoriter dari Gerakan Penindasan Menuju Politik Hegemoni. Yogyakarta: Pustaka Pelajar, 2000.

[12] Guillaume, A, The Influence of Yudaism on Islam. London: Oxford The Clarenon Press, 1972.

[13] Hadi, Sutrisno, Metodologi Research, Jilid 1 \& 2, Yogyakarta: UGM Press, 1991.

[14] Harahap, Syahrin, Metodologi Studi Tokoh Pemikiran Islam, Medan: Istiqamah Mulya Press, 2006.

[15] Haikal, Muhammad Husein, Hayat Muhammad. Beirut: Dar al-Maarif, 1983, (terj)

[16] Ali Audah, Sejarah Hidup Muhammad. Jakarta: Lintera Antar Nusa, 1995.

[17] Harun, Rochajat dan Sumarno Ap, Komunikasi Politik sebagai suatu pengantar. Bandung: Mandar Maju, 2006.

[18] Hisyam, Ibnu, Sirah al-Nabawiyyah. Kairo: Musthafa al-Bab al-Halabi, 1955.

[19] Hitti, Philip K., History of The Arab. London: The Macmillan Press Ltd, 1970.

[20] Iqbal, Muhammad, Masyarakat Madani Pada Masa Nabi Muhammad Saw. Dalam Miqot, Vol XXVI, No. 2, Juli 2002.

[21] Jasmadi, Piagam Madinah Dalam Perspektif Dakwah Nabi Muhammad SAW. Medan: PPS IAIN SU, 1996.

[22] Kantraprawira, Rusadi, Sistem Politik Indonesia. Bandung: Sinar Baru, 1983. 
[23] Katimin, Politik Islam Indonesia ; Membuka Tabir Perjuangan Islam Ideologis Dalam Sejarah Politik Nasional. Bandung: Citapustaka Media, 2007.

[24] Khan, Muhammad Zafrulah, Muhammad Seal of the Prophet. London: Routedgeang Kegan Paul, 1980.

[25] Kertapati,Ton, Dasar-Dasar Publisistik. Jakarta: Bina Akasara: 1981.

[26] Klalil, yauqi Abu, (terj) Muhammad Abdul ghoffar, Atlas Alquran. Jakarta: Almahira, 2006.

[27] Kholil, Syukur, Metodologi Penelitian Komunikasi. Bandung: Citapustaka Media, 2006.

[28] Nimmo, Dan, Komunikasi Politik ; Komunikator, Pesan dan Media. (Terj) Tjun Surjaman, Bandung: Remaja Rosdakarya, 2005.

[29] Lasswell, Harold, Politics: Who Gets, What, When, How. New York: Merdian Books, 1958.

[30] Madjid, Nurcholis, Cita-Cita Politik Kita dalam Aspirasi Umat Islam Indonesia, (ed) Bosco Carpallo dan Dasrizal. Jakarta: Leppenas, 1983.

[31] Marijan, Kacung, Sistem Politik Indonesia; Konsolidasi Demokrasi Pasca-Orde Baru. Jakarta: Kencana Prenada Media Group, 2010.

[32] Probonegoro, dan Nunik Kleden, Seni Memahami sebagai Metode Humaniora dalam masyarakat Indonesia. Dalam Jurnal LIPI jilid XXI no. 1, Jakarta: LIPI Press, 1994.

[33] Program Pascasarjana IAIN Sumatera Utara, Pedoman Penulisan Proposal dan Tesis.Medan: PPS IAIN SU, 2006.

[34] Rahmat, Jalaluddin, Psikologi Komunikasi. Bandung: Remaja Rosdakarya, 2003.

[35] Rauf, Maswadi, Mappa Nasrun, Indonesia dan Komunikasi Politik. Jakarta: Gramedia, 1993.

[36] Rousdy, Lathief, Dasar-Dasar Rhetorika Komunikasi dan Informasi. Medan: FA. Rinbow, 1985.

[37] Salim, Abdul Muin, Konsepsi Kekuasaan Politik Dalam Alquran, Jakarta: Raja Grafindo Persada, 2002.

[38] Soesanto, Astrid S, Komunikasi Sosial. Jakarta: Bina Cipta, 1975.

[39] Syafiie, Inu Kencana, Ilmu Politik, Jakarta: Rineka Cipta, 2010

[40] Syariati, Ali,(terj) Afif Muhammad, Rasulullah saw Sejak Hijrah hingga wafat. Jakarta: Pustaka Hidayah, 1992.

[41] Watt, W. Montgomery, Muhammmad; Propet and Statesman. New York: Oxford University Prass, 1964.

[42] ------------, Muhammad at Madina. London: Oxford Clarendon Press, 1977.

[43] Wajdi, Muhammad Farid, Dairah Ma'arif ; Alquran al- 'Isyrun. Beirut: Al-Maktabah al-'ilmiyah aljadidah, t.t.

[44] West, Richard, dkk, Introducing Communication Theory Analysis and Application. Singapore: Mc Grew Hill, 2007.

[45] Wok, Saodah, dkk, Teori-teori komunikasi. Kuala Lumpur: Percetakan Cergas (M) Sdn, Bhd, 2004 